\title{
Determination of bacteriocin-encoding genes of lactic acid bacteria isolated from traditional dairy products of Luxor province, Egypt
}

Rasha Mohamed Refay ${ }^{1}$, Hala Mohamed Abushady ${ }^{2}$, Sara Adel Amer ${ }^{3^{*}}$ (1) and Mahmoud Ahmed Mailam ${ }^{3}$

\begin{abstract}
Background: Researchers have focused on isolating and identifying the bacteriocin producing lactic acid bacteria from various food systems especially dairy products. Molecular techniques have been recently used for rabid identification of bacteriocins rather than time-consuming biochemical characters. Global climate disturbances can affect the diversity of beneficial microorganisms in dairy and their products, especially lactic acid bacteria, so it is worth to evaluate their bacteriocinogenicity in different climates. Thus, the aim of this study was to screen for predominant bacteriocin producing lactic acid bacteria $(L A B)$ in traditional dairy products of Luxor governorate at Upper Egypt and determine their bacteriocin-encoding genes.
\end{abstract}

Results: Eighty-six strains of the LAB were isolated from raw milk and traditional dairy product of Luxor province, Egypt, in which $76.1 \%$ and $23.9 \%$ were identified as lactic acid bacilli and cocci, respectively. On the basis of their antibacterial potentials, 30 out of $68 \mathrm{LAB}$ isolates were found to be antimicrobial producers. These isolates exhibited a potential antibacterial activity against Salmonella paratyphi B, Escherichia coli, Staphylococcus aureus, and Proteus mirabilis, except for Listeria monocytogenes. LAB isolates were analyzed using species-specific PCR; results emphasized that 22 of isolates were identified as Lactobacillus plantarum, while 8 were Leuconostoc mesenteroides. According to the sequencing of isolates, two strains named Lactobacillus plantarum Egypt 2018 (accession no. MH817034) and Leuconostoc mesenteroides Egypt 2018 (accession no. MH817035) were identified. Detection of bacteriocin-encoding genes was performed by polymerase chain reaction (PCR). The results emphasized that almost all tested $L b$. plantarum strains $(n=10)$ possess both plnA and plnEF genes, whereas the gene encoding mesentericin Y105 was detected in one Lc. mesenteroides of the examined isolates.

Conclusions: This study was effective for the rapid detection of bacteriocin producing strains within dairy products. Extracted bacteriocin could be a valuable source of natural food biopreservative.

Keywords: Bacteriocin gene, Egypt dairy products, Lactic acid bacteria, Mesentericin Y105, Plantaricin EF, Plantaricin A, Species specific primer

\footnotetext{
* Correspondence: Dsaramer55@yahoo.com

${ }^{3}$ Agricultural Research Centre (ARC), Food Technology Research Institute

(FTRI), Giza, Egypt

Full list of author information is available at the end of the article
}

\section{Springer Open}

(c) The Author(s). 2020 Open Access This article is licensed under a Creative Commons Attribution 4.0 International License, which permits use, sharing, adaptation, distribution and reproduction in any medium or format, as long as you give appropriate credit to the original author(s) and the source, provide a link to the Creative Commons licence, and indicate if changes were made. The images or other third party material in this article are included in the article's Creative Commons licence, unless indicated otherwise in a credit line to the material. If material is not included in the article's Creative Commons licence and your intended use is not permitted by statutory regulation or exceeds the permitted use, you will need to obtain permission directly from the copyright holder. To view a copy of this licence, visit http://creativecommons.org/licenses/by/4.0/. 


\section{Background}

Fresh and unpasteurized milk in Egypt is frequently used to prepare traditional products such as White, Karish, Mish, and Ras cheese, yogurt, Rayeb, Labneh, and butter. The local homemade dairy products in Upper Egypt depend on the spontaneous activity of the milk indigenous microbial population itself. Lactic acid bacteria (LAB) are occurring naturally as indigenous microflora in raw milk which can be taken as starter strains with unique characteristics. In addition, metabolic products produced by $\mathrm{LAB}$ related to the organoleptic, textural profile, and shelf life of the foods [1]. LAB are generally recognized as safe (GRAS) status, which increases their application in industrial-scale especially health-promoting products [2]. According to the dairy technology point of view, the subsequent genera are considered the foremost LAB: Aerococcus, Enterococcus, Lactobacillus, Lactococcus, Leuconostoc, Pediococcus, and Streptococcus [3].

European Union has developed a project under ECLAIR programme, AGRE-0064 for the isolation of new starter cultures from traditional cheese and fermented milk across Europe [4]. Nevertheless, in Egypt, traditional LAB flora still waits for scientific attention because of uncontrolled industrialization.

The majority of starter cultures which are food grade $\mathrm{LAB}$, applied in the dairy industry, have enormous antimicrobial potential. Bacteriocins which are ribosomally synthesized peptides or proteins are produced by most of the LAB species. These bacteriocins are able to kill phylogenetically related strains. Owing to their antagonistic activities, bacteriocins can be used as non-thermal means to prevent spoilage [5].

Based on molecular weight, genetics, and chemical properties, bacteriocins are classified to four major groups: class I which is small peptide inhibitors termed as lantibiotics; class II comprises small heat-stable proteins that has five subclasses; class III contains large, heat-labile protein, and this class has two subclasses; and finally class IV that are complex bacteriocins containing lipid or carbohydrate sections [6].

The traditional screening strategies consume time and effort. The researchers are continuously trying to develop rapid screening methods like polymerase chain reaction (PCR) method. Some researchers have designed specific primers that amplify particular genera or species of LAB [7]; others have developed specific primers for bacteriocin coding genes or regulation related genes for rapid detection of bacteriocins [8, 9]. These advanced methods have led to a better understanding of the microbial communities existing in a variety of ecosystems, like the gut microbiota [10].

Little is known about the LAB microbial population in Luxor province at Upper Egypt. Luxor has a hot desert climate. During daytime, temperatures exceed $40{ }^{\circ} \mathrm{C}$ (104 $\left.{ }^{\circ} \mathrm{F}\right)$; this will give an opportunity to isolate LAB strains, which are able to tolerate high temperatures. Thus, the aim of this study was exploring LAB strains found in raw milk and traditional dairy products of Luxor province, evaluating their antibacterial activity, using molecular techniques (PCR) for rapid screening of these strains at the species level by using a species-specific LAB primer and for determining their bacteriocins-encoding genes.

\section{Methods}

\section{Collection of samples}

This study was conducted from March to May 2018. A total of 23 different traditional fermented milk dairy samples consist of 6 samples of raw milk (cow, buffalo, and goat), 8 samples of Laban rayeb (cow, buffalo, and goat), 1 sample of cheddar cheese, 3 samples of Karish cheese, 3 samples of Mish, and 2 samples of butter, which were collected from the surrounding area of the city of Luxor, Egypt. Samples were collected in sterilized bottles and delivered to laboratory using icebox for microbiological examination. Samples were kept in a refrigerator (around $4{ }^{\circ} \mathrm{C}$ ) until the analysis began.

\section{Isolation and enumeration of lactic acid bacteria}

For isolation of LAB, approximately $10 \mathrm{~g}$ of each sample was homogenized with sterile physiological peptone water $(10 \%)$ and serially diluted in the same diluent. A volume of $0.1 \mathrm{ml}$ of appropriate dilutions was spread plated on MRS (Oxoid) agar media [11] and incubated under aerobic and anaerobic conditions (an anaerobic gas pack system-Oxoid) at $37{ }^{\circ} \mathrm{C}$ for $2-5$ days. Typical $\mathrm{LAB}$ characteristic colonies were enumerated $(\mathrm{cfu} / \mathrm{ml})$, then randomly picked up and purified by streaking two or three times on fresh MRS agar plates. Isolates were preserved at $4{ }^{\circ} \mathrm{C}$ in MRS broth (Oxoid) [12], followed by macroscopic and microscopic examinations.

\section{Phenotypic characterization}

The colonies displaying the general characteristics of $\mathrm{LAB}$ were chosen from each plate for physiological and biochemical tests. LAB were characterized by Gram staining, catalase reaction, oxidase test, milk coagulation activities, motility, esculin hydrolysis, and growth for 48 $\mathrm{h}$ at 37 and $45^{\circ} \mathrm{C}$ for mesophilic and thermophilic LAB, respectively $[13,14]$.

\section{Detection of antibacterial activity}

Antibacterial activity of all LAB isolates was first screened with agar spot diffusion [15]. Then, potential antibacterial LAB strains were investigated by well diffusion methods [16].

Indicator strains used Listeria monocytogenes, Staphylococcus aureus, Proteus mirabilis, Salmonella paratyphi B, and Escherichia coli, which were kindly 
obtained from central laboratories in Cairo, were inoculated in $100 \mathrm{ml}$ of peptone water, and the concentration was matched against 0.5 Mcfarland Standard and then diluted by $1: 100$ to obtain a concentration of $1.0 \times 10^{6}$ $\mathrm{CFU} / \mathrm{ml}$.

For the preparation of crude bacteriocin, $10 \mathrm{ml}$ of MRS broth was inoculated with $0.1 \mathrm{ml}$ of freshly prepared culture of isolated strains individually, then incubated for $18 \mathrm{~h}$ at $37{ }^{\circ} \mathrm{C}$. The grown culture was centrifuged at $4000 \times g$ for $4 \mathrm{~min}$ at room temperature in the centrifuge tubes. The supernatant of overnight culture of isolates was heated at $80{ }^{\circ} \mathrm{C}$ for $10 \mathrm{~min}$ and the $\mathrm{pH}$ adjusted to 6.5 using $1 \mathrm{M} \mathrm{NaOH}$, to obtain crude bacteriocin [17].

\section{Agar spot diffusion method}

Muller Hinton Agar (MHA) was poured in plates and surface seeded with indicator strains. Ten microliters of crude bacteriocin or of positive gentamicin disc (10 ug) and negative (sterilized MRS broth) controls were spotted on the surface of inoculated agar, and plates were incubated overnight at $37{ }^{\circ} \mathrm{C}$ for $24 \mathrm{~h}$. After incubation, inhibition was indicated by a clear zone around spots.

\section{Well diffusion method}

Wells were made on MHA plates containing indicator strains, and each well was filled with $50 \mu \mathrm{l}$ of crude bacteriocin. Eventually, after an incubation period $\left(37^{\circ} \mathrm{C}\right.$ for $24 \mathrm{~h}$ ), inhibition was indicated by a clear zone around each well.

\section{Extraction of bacteriocin and determination of its antibacterial activity titer}

Bacteriocin was precipitated from the crude extract by the addition of ammonium sulfate; a 24-h old culture of the selected bacteriocin producing LAB strains was centrifuged $(4000 \times g, 4 \mathrm{~min})$. The peptidic fraction precipitated from the supernatant by the addition of $80 \%$ ammonium sulfate $\left[\left(\mathrm{NH}_{4}\right)_{2} \mathrm{SO}_{4}\right]$ in a cold condition (temperatures of 5 to $10{ }^{\circ} \mathrm{C}$ ) to achieve $80 \%$ saturation, with stirring gently. Then, it was left overnight. After that, the precipitate was separated from the filtrate by centrifugation (Hitachi-CS150FNX) under cooling at $13.000 \mathrm{rpm}$ for $10 \mathrm{~min}$. After centrifugation, the precipitate was dissolved in $0.05 \mathrm{M}$ phosphate buffer solution at $\mathrm{pH}$ 7.0. The dissolved precipitate was used for the bacteriocin activity test, while the rest was stored in a freezer $\left(-20{ }^{\circ} \mathrm{C}\right)[18]$. Antibacterial activity titer of extracted bacteriocin was determined by using the agar well diffusion method described before but by using two-fold serial dilutions of the bacteriocin. Each well was filled with $50 \mu \mathrm{l}$ of bacteriocin on MHA previously seeded with $100 \mu \mathrm{l}$ suspension of each indicator strain. The antimicrobial activity of bacteriocin was defined as the reciprocal of the highest dilution that showed inhibitory zone, and it was expressed as arbitrary unit (AU).

\section{Molecular identification \\ Genomic DNA extraction}

On the basis of the morphological characteristics and antibacterial potential, 30 isolates were selected. Bacterial isolates were subcultured on MRS medium and incubated at $30{ }^{\circ} \mathrm{C}$ for $48-72 \mathrm{~h}$. DNA extraction kit (QIAamp DNA mini kit, Dalian, China) was used to extract and purify genomic DNA from LAB strains.

\section{Species-specific recA primer}

Selected isolates were investigated using different species-specific recA primers for PCR identification of the isolate at the species level. Primers used were for Leuconostoc (Lc) mesenteroides, Lactobacillus (Lb.) plantarum, and Lactococcus lactis [19]. The sequences of PCR primers are shown in Table 1. According to Emerald Amp GT PCR Master Mix (Takara), $25 \mu$ of reaction mixture containing $6 \mu \mathrm{l}$ of bacterial DNA template, $1 \mu \mathrm{l}$ of each primer, $12.5 \mu \mathrm{l}$ of Emerald Amp GT PCR mastermix (2× premix), and $4.5 \mu$ of PCR grade water were prepared. The thermal cycling program was followed according to PCR mastermix kit that briefly consisted of an initial denaturation step at $94{ }^{\circ} \mathrm{C}$ for 5 min and 35 cycles of $94{ }^{\circ} \mathrm{C}$ for $30 \mathrm{~s}, 55^{\circ} \mathrm{C}$ for $30 \mathrm{~s}$, and $72{ }^{\circ} \mathrm{C}$ for $30 \mathrm{~s}$, followed by a final extension for $7 \mathrm{~min}$ at $72{ }^{\circ} \mathrm{C}$. The amplified products were visualized by electrophoresis in $1.5 \%$ agarose gels stained with $0.5 \mu \mathrm{g} / \mathrm{ml}$ ethidium bromide. The gel was photographed by a gel documentation system [20], and the data was analyzed through computer software (reference lab for veterinary quality control on poultry production, Animal health research institute, Egypt).

\section{Sequences analysis}

For further identification of the lactobacilli examined by species-specific primers, we amplified and sequenced two strains of $L b$. plantarum and $L c$. mesenteroides isolates using the $\operatorname{rec} A$ gene sequencing. A purified RTPCR product was sequenced in the forward and/or reverse directions on an Applied Biosystems 3130 automated DNA Sequencer (ABI, 3130, USA) using a ready reaction Bigdye Terminator V3.1 cycle sequencing kit (Perkin-Elmer/Applied Biosystems, Foster City, CA). A BLAST $^{\circ}$ analysis (Basic Local Alignment Search Tool) (NCBI, http://www.blast.ncbi.nlm.nih.gov) was initially performed to establish sequence identity to GenBank accessions [21].

\section{Phylogenetic analysis}

A comparative analysis of sequences was performed using the Clustal W multiple sequence alignment 
Table 1 Specific oligonucleotide primers sequences used throughout this study

\begin{tabular}{|c|c|c|c|c|}
\hline Primer & Target gene & Primer sequence & Amplified product & Reference \\
\hline \multirow[t]{3}{*}{ Bacterial strain gene } & Lb. plantarum, recA gene & $\begin{array}{l}\text { F: } 5^{-} \text {CAGAATTGAGCTGGTGGTGG3- }^{-} \\
\text {R: } 5 \text { TGTACTTCGCAACCAGAT3- }\end{array}$ & $210 \mathrm{bp}$ & [19] \\
\hline & Lactococcus lactis subsp. Lactis, recA gene & $\begin{array}{l}\text { F: } 5^{5} \text { ATGCGTAAACTTGCAGGAC3- }^{-} \\
\text {R: } 5^{5} \text { CAACCTTGAATGGTGGAG3- }^{-}\end{array}$ & $262 \mathrm{bp}$ & \\
\hline & Lc. mesenteroides, recA gene & $\begin{array}{l}\text { F: 5ATACAGGCGAACAGGGGATTA3- } \\
\text { R: } 5^{-} \text {GGGTGTAGTTCTGGGTTTC3- }^{-}\end{array}$ & $269 \mathrm{bp}$ & \\
\hline \multirow[t]{4}{*}{ Bacteriocin gene } & MesY & $\begin{array}{l}\text { F: 5ATGACGAATATGAAGTC3- } \\
\text { R: 5TTACCAAAATCCATTTCC3 }\end{array}$ & 186 bp & [23] \\
\hline & PInEF & $\begin{array}{l}\text { F: GGCATAGTTAAAATTCCCCCC } \\
\text { R:CAGGTTGCCGCAAAAAAAG }\end{array}$ & $428 \mathrm{bp}$ & [25] \\
\hline & PInA & $\begin{array}{l}\text { F: GTACAGTACTAATGGGAG } \\
\text { R: CTTACGCCATCTATACG }\end{array}$ & $450 \mathrm{bp}$ & \\
\hline & $P \ln C$ & $\begin{array}{l}\text { F: GGTGGCGACAGGAGATTTAC } \\
\text { R: AGAAACGCGTTCCGATTTA }\end{array}$ & $353 \mathrm{bp}$ & [24] \\
\hline
\end{tabular}

program, version 1.83 of MegAlign module of the Lasergene DNAStar software Pairwise, and phylogenetic analyses were done using neighbor-joining tree with Maximum Composite Likelihood substitution model in MEGA6. Numbers at nodes represent measures of robustness depend on 1000 bootstrap replications in MEGA6 [22].

\section{Detection of genes encoding bacteriocin production}

PCR assay was used to determine bacteriocin genes, including mesY, $p \ln \mathrm{A}, p \ln \mathrm{EF}$, and $p \ln \mathrm{C}$. $\mathrm{PCR}$ primers (Metabion, Germany) were used according to [23-25] and are presented in Table 1. PCR conditions were similar to all the genes: an initial denaturation step of $94{ }^{\circ} \mathrm{C}$ for $5 \mathrm{~min}, 34$ cycles of $94{ }^{\circ} \mathrm{C}$ for $30 \mathrm{~s}$, annealing $55^{\circ} \mathrm{C}$ for $30 \mathrm{~s}$, and extension $72{ }^{\circ} \mathrm{C}$ for $30 \mathrm{~s}$, followed by a final extension at $72{ }^{\circ} \mathrm{C}$ for $7 \mathrm{~min}$. The amplified products were visualized by electrophoresis in 1.5\% agarose gels as previously described [9].

\section{Results}

Isolation and identification of LAB from dairy samples

The microbial population of LAB cultivated on MRS revealed that Karish and cheddar cheese presenting the

Table 2 Samples, sampling locations, and lactic acid bacteria (LAB) count (log cfu/ml or g) of milk and dairy products

\begin{tabular}{|c|c|c|c|c|c|}
\hline \multirow[t]{2}{*}{ Sample types } & \multirow{2}{*}{$\begin{array}{l}\text { Sampling } \\
\text { location }\end{array}$} & \multirow{2}{*}{$\begin{array}{l}\text { No. of } \\
\text { samples }\end{array}$} & \multirow[t]{2}{*}{ Sample codes } & \multicolumn{2}{|c|}{ Lactic acid bacteria count (log CFU/ml) } \\
\hline & & & & Average (mean \pm SD) & Range \\
\hline \multirow[t]{3}{*}{ Raw milk } & Elbaqala & 4 & GM19, CM5, CM3, BM2 & $3.05 \pm 1.02$ & $1.60-4.00$ \\
\hline & Raiyna & 1 & CM8 & $2.40 \pm 0.09$ & $2.35-2.49$ \\
\hline & Luxor & 1 & CM12 & $3.20 \pm 0.02$ & $3.18-3.22$ \\
\hline \multirow[t]{5}{*}{ Rayeb } & Elbaqala & 4 & GR20, BR6, LR7, LR4 & $5.18 \pm 4.52$ & $0.60-9.30$ \\
\hline & Raiyna & 1 & LR17 & $1.80 \pm 0.02$ & $1.78-1.82$ \\
\hline & Luxor & 1 & LR15 & $2.70 \pm 0.09$ & $2.61-2.79$ \\
\hline & Elmeris & 1 & LR21 & $1.30 \pm 0.09$ & $1.21-1.39$ \\
\hline & Esna & 1 & LR1 & $2.70 \pm 0.04$ & $2.66-2.74$ \\
\hline \multirow[t]{3}{*}{ Karish cheese } & Elbaqala & 1 & KC16 & $5.60 \pm 0.09$ & $2.51-2.69$ \\
\hline & Raiyna & 1 & KC9 & $13.80 \pm 0.02$ & $13.78-13.82$ \\
\hline & Elmeris & 1 & KC23 & $4.20 \pm 0.02$ & $4.18-4.22$ \\
\hline Cheddar cheese & Luxor & 1 & CC18 & $5.80 \pm 0.02$ & $5.78-5.82$ \\
\hline \multirow[t]{2}{*}{ Mish } & Elbaqala & 2 & Ml13, Ml14 & $1.67 \pm 1.20$ & $0.82-2.52$ \\
\hline & ELroziqat & 1 & Ml10 & $2.09 \pm 0.00$ & 2.09 \\
\hline \multirow[t]{2}{*}{ Butter } & Elbaqala & 1 & BU11 & $1.82 \pm 0.02$ & $1.80-1.84$ \\
\hline & Elmeris & 1 & BU22 & $4.00 \pm 0.00$ & 4.00 \\
\hline
\end{tabular}


highest bacterial count, followed by Laban rayeb, while the least count recorded with Mish (Table 2). A total of 119 colonies were recovered from 23 fermented milk samples. Sixty-eight isolates only were considered as LAB, which was characterized by positive Gram, negative catalase, not motile, and ability to live in microaerophilic conditions. The colony morphology and microscopic characteristic were considered (Fig. 1). The most frequently isolated colonies which were observed in different samples were those with milkywhite, circular, convex, and moist colonies, followed with a creamy, smooth, and slimy colonies. It was detected from the microscopic characteristics of LAB that rod shape LAB were as many as 51 isolates (75\%), and coccus-shaped were 17 isolates (25\%). The bacterial cells were mostly long rods, and sometimes they were coccoid, while coccoid cells were in single and diplo shapes. The majority of isolates were able to grow at $45{ }^{\circ} \mathrm{C}$, while the other isolates had an optimum temperature around $37{ }^{\circ} \mathrm{C}$. Fifty-nine percent of bacilli were found to be thermophilic, and $14 \%$ were mesophilic, while $10 \%$ of the cocci were thermophilic, and $17 \%$ were a mesophilic type. Thirteen percent of the bacilli and $8 \%$ of the cocci had the ability to hydrolyze bile esculin salts.

\section{Antibacterial activity}

According to the agar spot diffusion test, all the $68 \mathrm{LAB}$ isolates displayed an inhibitory effect against tested foodborne indicator strains by initial screening of supernatant. The antibacterial activities of the crude bacteriocin of 68 $\mathrm{LAB}$ strains were further investigated by well diffusion method. The results show that only 30 LAB strains have antibacterial activity (Table 3 ). The highest antibacterial activity was recorded against S. paratyphi B (29 LAB strains) and Staph. aureus (26 LAB strains) at various degrees. The highest inhibition zone is recorded against Staph. aureus, mainly by isolates from Laban rayeb and Karish cheese. However, none of the isolates displayed antibacterial activity against $L$. monocytogenes.

\section{Molecular identification}

PCR analysis was carried out for 30 selected isolated strains by using species-specific primers for $L c$. mesenteroides, Lb. plantarum, and Lactococcus lactis (Table 4 and Fig. 2). Results revealed that isolates contain 8 coccoid isolates which were identified as $L c$. mesenteroides, and 22 bacilli isolates were identified as Lb. plantarum, while neither of them belongs to Lactococcus lactis.

For further study, we selected randomly strain no. (1) Lb. plantarum and strain no. (2) Lc. mesenteroides for sequencing analysis. The sequence identity of $L b$. plantarum Egypt 2018 was deposited in NCBI under GenBank accession number of MH817034, and the accession number for the Lc. mesenteroides Egypt 2018 is MH817035.

Lb. plantarum Egypt 2018 has a 100\% similarity with the nucleotide sequence of $L b$. plantarum subsp. plantarum ATCC 14917T (GenBank: AJ621668.1) among other closely related strains (Fig. 3), while the nucleotides sequence of $L c$. mesenteroides subsp. jonggajibkimchii strain DRC1506 with accession no. CP014611.1 in Korea comprises a similarity of $99.3 \%$ to our strain $L c$. mesenteroides Egypt 2018 (Fig. 4).

\section{Detection of bacteriocin activity}

Based on the results of antibacterial activity, bacteriocin activity was measured for 11 selected potent antibacterial strains. The results are presented in the Table 5 . Strain no. 13 recorded the highest antibacterial activity (160 AU/ml) against indicator strain (Staph. aureus). While the lowest antibacterial activity was recorded by strains no. 1 and 18, other strains showed a similar moderate antibacterial activity of $80(\mathrm{AU} / \mathrm{ml})$.

\section{Detection of the bacteriocin genes}

Selected strains were tested for the presence of genes encoding bacteriocin: $p \ln \mathrm{A}, p \ln \mathrm{C}$ and $p \ln \mathrm{EF}$, and mes $\mathrm{Y}$ gene. Results emphasized that $p \ln \mathrm{EF}$ is detected in all tested $L b$. plantarum strains, except for strain no. 19. $P \ln \mathrm{A}$ genes were also tested for some $p \ln \mathrm{EF}$ genepositive strains, and they gave positive results of $p \ln \mathrm{A}$ in all tested strains, while mesY gene was found in one of the two strains of Lc. mesenteroides (Table 5, Fig. 5).

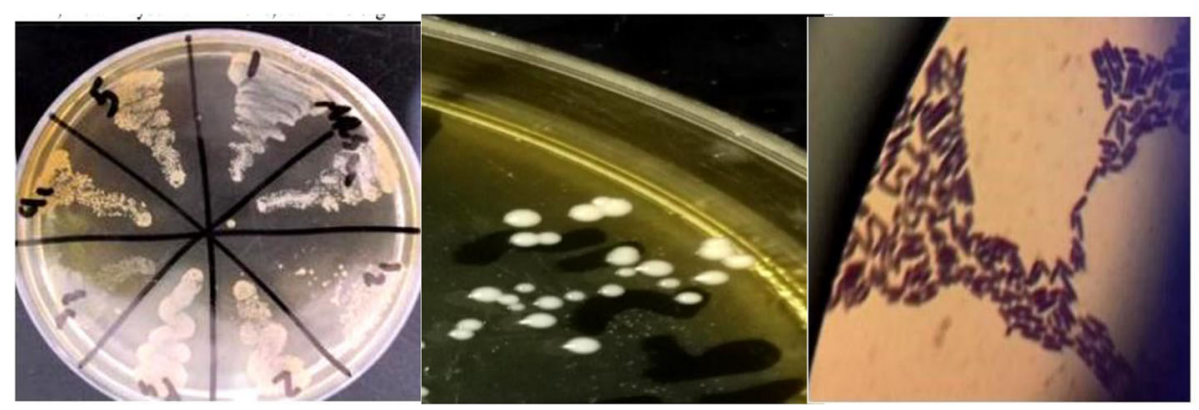

Fig. 1 Morphological and microscopic characters of isolated strain (Lb. plantarum) 
Table 3 Antibacterial activity of isolated lactic acid bacterial strains by diffusion test and well diffusion test

\begin{tabular}{|c|c|c|c|c|c|c|c|c|c|c|c|}
\hline \multirow{2}{*}{$\begin{array}{l}\text { Sample } \\
\text { no. }\end{array}$} & \multirow[t]{2}{*}{ Species } & \multicolumn{2}{|c|}{ S. paratyphi B } & \multicolumn{2}{|l|}{ E.coli } & \multicolumn{2}{|c|}{ Staph. aureus } & \multicolumn{2}{|c|}{ Pr. mirabilis } & \multicolumn{2}{|c|}{ L. monocytogenes } \\
\hline & & $S$ & W & $S$ & W & $S$ & W & $S$ & W & $S$ & W \\
\hline 1 & $P$ & + & + & + & + & ++ & + & + & + & - & - \\
\hline 2 & $L$ & + & + & + & + & +++ & +++ & ++ & ++ & - & - \\
\hline 3 & $P$ & + & + & + & + & - & - & + & + & - & - \\
\hline 4 & $P$ & + & + & - & - & - & - & + & + & - & - \\
\hline 5 & L & + & + & - & - & - & - & + & + & - & - \\
\hline 6 & $L$ & ++ & ++ & - & - & - & - & + & + & - & - \\
\hline 7 & $P$ & ++ & ++ & - & ++ & +++ & +++ & ++ & +++ & - & - \\
\hline 8 & $P$ & ++ & ++ & - & - & ++ & +++ & - & - & - & - \\
\hline 9 & $P$ & ++ & ++ & - & - & + & ++ & ++ & - & - & - \\
\hline 10 & $P$ & ++ & ++ & - & - & - & - & - & - & - & - \\
\hline 11 & $L$ & - & ++ & - & - & ++ & ++ & - & + & - & - \\
\hline 12 & P & ++ & + & - & - & + & ++ & - & ++ & - & - \\
\hline 13 & $P$ & + & ++ & - & ++ & + & ++ & - & + & - & - \\
\hline 14 & $P$ & - & ++ & - & + & + & +++ & ++ & + & - & - \\
\hline 15 & $P$ & ++ & ++ & ++ & ++ & ++ & +++ & + & + & - & - \\
\hline 16 & $L$ & ++ & ++ & - & - & ++ & +++ & + & + & - & - \\
\hline 17 & $L$ & ++ & ++ & - & + & + & ++ & + & - & - & - \\
\hline 18 & $P$ & ++ & ++ & ++ & + & ++ & +++ & - & - & - & - \\
\hline 19 & P & ++ & ++ & - & + & ++ & + & - & - & - & - \\
\hline 20 & $L$ & ++ & + & - & - & ++ & ++ & - & - & - & - \\
\hline 21 & $P$ & ++ & + & - & + & ++ & +++ & - & - & - & - \\
\hline 22 & $P$ & ++ & + & + & + & +++ & ++ & - & + & - & - \\
\hline 23 & P & + & ++ & - & + & ++ & + & - & +++ & - & - \\
\hline 24 & $P$ & + & ++ & - & + & +++ & +++ & - & + & - & - \\
\hline 25 & $P$ & + & ++ & - & - & +++ & ++ & - & - & - & - \\
\hline 26 & $P$ & ++ & ++ & - & + & + & +++ & - & - & - & - \\
\hline 27 & P & ++ & ++ & + & + & ++ & +++ & + & ++ & - & - \\
\hline 28 & P & + & + & + & + & ++ & + & + & + & - & - \\
\hline 29 & L & ++ & ++ & - & - & + & ++ & + & + & - & - \\
\hline \multirow[t]{2}{*}{30} & P & ++ & + & + & + & ++ & + & ++ & + & - & - \\
\hline & Gentamicin 10 & +++ & & +++ & & +++ & & +++ & & +++ & \\
\hline
\end{tabular}

$S$ spot diffusion test, $W$ well diffusion test, $P$ Lb. plantarum, $L L C$. mesenteroides

Diameter of the inhibition zone: (+) weak (3-5) $\mathrm{mm},(++)$ intermediate (6-10) $\mathrm{mm},(+++)$ strong $>10 \mathrm{~mm},(-)$ no growth 
Table 4 Molecular identification of lactic acid bacterial isolates by using species-specific primers

\begin{tabular}{|c|c|c|c|c|}
\hline \multirow{2}{*}{$\begin{array}{c}\text { Sample } \\
\text { No. }\end{array}$} & \multirow{2}{*}{$\begin{array}{c}\text { Sample } \\
\text { ID }\end{array}$} & \multicolumn{2}{|c|}{ Results } & \multirow[b]{2}{*}{ Lc. mesenteroides } \\
\hline & & Lb. plantarum & L. lactis & \\
\hline 1 & $\mathrm{LR}^{*}{ }^{*}$ & + & $\mathrm{N}$ & $\mathrm{N}$ \\
\hline 2 & $\mathrm{LR}_{1}{ }^{* *}$ & $\mathrm{~N}$ & - & + \\
\hline 3 & $\mathrm{LR}_{2}$ & + & $\mathrm{N}$ & $\mathrm{N}$ \\
\hline 4 & BM2 & + & $\mathrm{N}$ & $\mathrm{N}$ \\
\hline 5 & CM3 & $\mathrm{N}$ & - & + \\
\hline 6 & $\mathrm{CM}_{3}$ & $\mathrm{~N}$ & - & + \\
\hline 7 & LR4 & + & $\mathrm{N}$ & $\mathrm{N}$ \\
\hline 8 & CM8 & + & $\mathrm{N}$ & $\mathrm{N}$ \\
\hline 9 & MI10 & + & $\mathrm{N}$ & $\mathrm{N}$ \\
\hline 10 & $\mathrm{MI}_{10}$ & + & $\mathrm{N}$ & $\mathrm{N}$ \\
\hline 11 & $\mathrm{MI}_{10}$ & $\mathrm{~N}$ & - & + \\
\hline 12 & BU11 & + & $\mathrm{N}$ & $\mathrm{N}$ \\
\hline 13 & BU11 2 & + & $\mathrm{N}$ & $\mathrm{N}$ \\
\hline 14 & $\mathrm{BU} 11_{3}$ & + & $\mathrm{N}$ & $\mathrm{N}$ \\
\hline 15 & CM12 & + & $\mathrm{N}$ & $\mathrm{N}$ \\
\hline 16 & MI13 & $\mathrm{N}$ & - & + \\
\hline 17 & $\mathrm{MI}_{13}$ & $\mathrm{~N}$ & - & + \\
\hline 18 & MI14 & + & $\mathrm{N}$ & $\mathrm{N}$ \\
\hline 19 & LR15 & + & $\mathrm{N}$ & $\mathrm{N}$ \\
\hline 20 & $\mathrm{KC} 16^{-}$ & $\mathrm{N}$ & - & + \\
\hline 21 & $\mathrm{KC}_{1} 6_{5}$ & + & $\mathrm{N}$ & $\mathrm{N}$ \\
\hline 22 & GM19 & + & $\mathrm{N}$ & $\mathrm{N}$ \\
\hline 23 & LR21 & + & $\mathrm{N}$ & $\mathrm{N}$ \\
\hline 24 & BU22 & + & $\mathrm{N}$ & $\mathrm{N}$ \\
\hline 25 & $\mathrm{CM} 8_{1}$ & + & $\mathrm{N}$ & $\mathrm{N}$ \\
\hline 26 & $\mathrm{KC} 165^{\circ}$ & + & $\mathrm{N}$ & $\mathrm{N}$ \\
\hline 27 & LR7 & + & $\mathrm{N}$ & $\mathrm{N}$ \\
\hline 28 & LR17 & + & $\mathrm{N}$ & $\mathrm{N}$ \\
\hline 29 & $\mathrm{LR} 7_{1}$ & $\mathrm{~N}$ & - & + \\
\hline 30 & $\mathrm{CC} 18$ & + & $\mathrm{N}$ & $\mathrm{N}$ \\
\hline
\end{tabular}

\section{Discussion}

The rich biodiversity of natural dairy products can be considered as excellent sources of LAB strains [26]. Karimi et al. [27] described factors influencing the dairy product ecosystem of probiotics count in milk products which could be microbial interactions, acidity, oxygen, growth promoters, hydrogen peroxide, ripening factors, food additives, salt, and storage temperature. The microbial content of raw milk is important for the production of hygienic dairy foods [28]. The results found in this research revealed that Karish cheese samples have the highest bacterial count, while Mish samples have the lowest LAB count, and that may be related to the high salt content of Mish. High numbers of LAB were mentioned previously in Egypt $\left(1.1 \times 10^{9} \pm 1.6 \times 10^{9} \mathrm{CFU} / \mathrm{g}\right)$ and were recorded for Karish cheese, Whey, and Ras cheese in Gharbiya and Minufiyah [29]. Also, a high and significant diversity of LAB was identified in the samples of Coalho cheese produced in the State of Paraíba from $10^{8}$ to $10^{11} \mathrm{CFU} / \mathrm{g}$, which also presented an elevated number of colonies that may be as a consequence of the traditional manufacturing process [30]. Besides, the fact that raw milk is rich in lactic and non-lactic bacteria, which may originate from the mammary gland, the environment, water, or other tools involved in the milk production process. This nonpasteurized milk is the main source of the Karish cheese microbiota, by means it was processed with. All these factors could be a reason behind the elevated numbers of colonies detected in Karish cheese.

The identification of predominant bacteriocin producing LAB was started by looking at the shape of the colonies of each sample followed by Gram staining, catalase testing, and then determining its antibacterial activity. Results of this examination indicated that 68 out of 161 isolates were considered as LAB. In harmony with our results, Moulay et al. [31] had isolated microorganisms from goat milk and found that only 13 isolates from a total of 138 isolates belonged to LAB group. Isolated LAB strains were classified to either cocci, bacilli, or coco bacilli. In general, the dominant LAB were those with rod-shaped. A similar observation was noted by Yelnetty et al. [32] who found that rod shape represents $61.5 \%$ of LAB strains isolated from spontaneous fermented local goat milk.

Thermophilic bacilli were the dominant microflora of dairy products and raw milk samples of Luxor and that was expected from such high temperature climate. Similar observations of species isolated from fermented foods by Jagadeeswari et al. [33]. Otherwise, Franciosi et al. [34] found that the mesophilic cocci were dominant over thermophilic cocci, and the mesophilic rods were dominant over thermophilic rods in fermented food.

Consumers are always concerning about the microbiological hazardous of raw milk involved in the manufacture of fermented dairy products like cheeses because of the absence of thermal inactivation of pathogenic microbiota. Nevertheless, Brooks et al. [35] showed that all raw milk cheeses were negative for pathogens such as Listeria monocytogenes, Salmonella, and Escherichia coli O157:H7. Unexpected, pasteurized milk cheeses were found to be a source of infection of Listeria-associated foodborne illnesses outbreaks in Germany from 2006 till 2007 [36]. The maintenance of the hygiene and safety of dairy products could be related to the bacteriocins produced by LAB strains.

The isolated 68 LAB displayed antibacterial activity against 4 of indicator strains. It is known that LAB are able to produce several antimicrobial compounds which include hydrogen peroxide and organic acids. In order to ensure that the inhibition was caused by the bacteriocin only, preparation of cell free-supernatant at $\mathrm{pH} 6.5$ was carried out to eliminate the effect of acids produced by lactic acid bacteria against indicator strains. Also, to exclude the effect of hydrogen peroxide, producer strains 


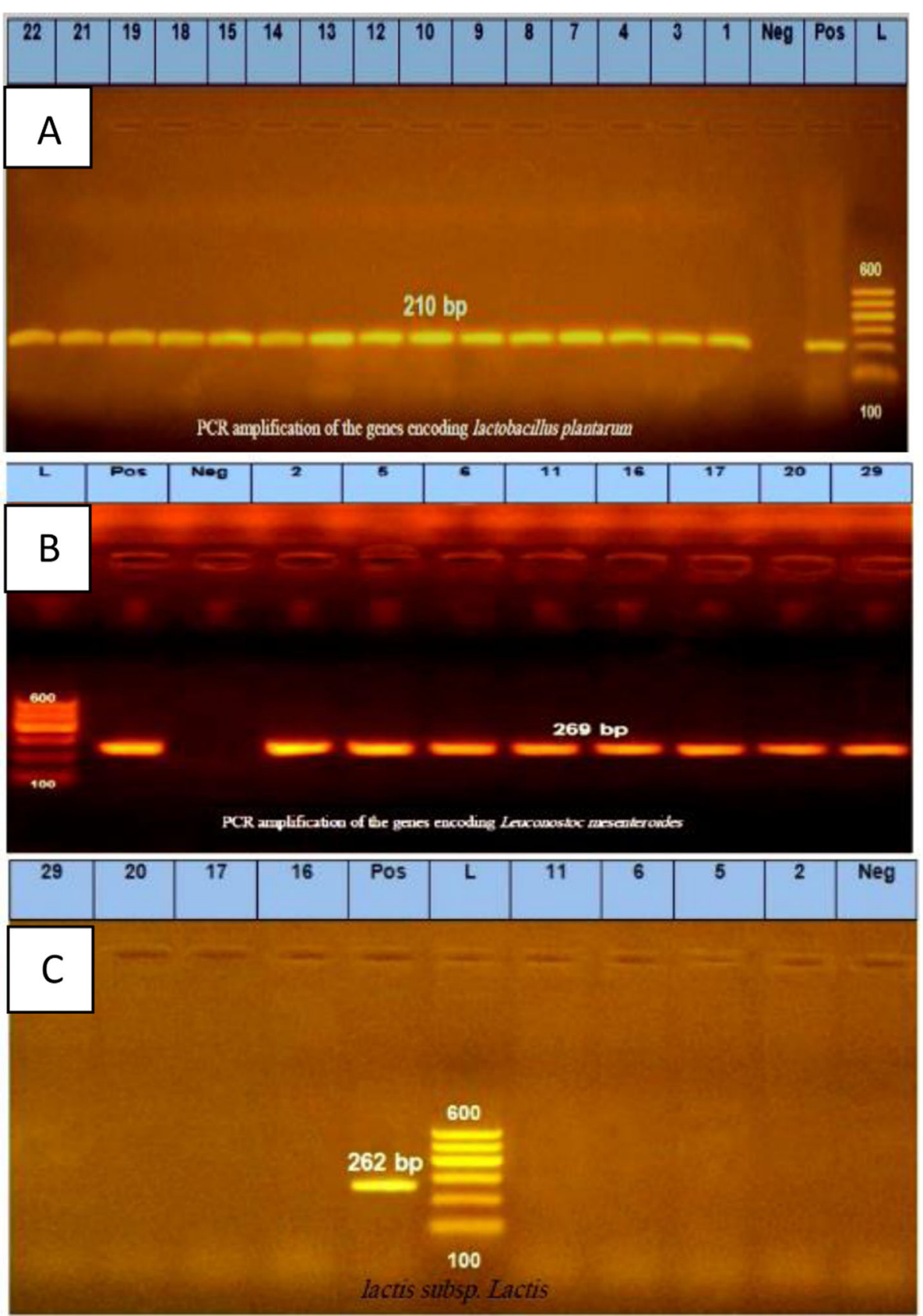

Fig. 2 Amplification products obtained from lactic acid bacterial isolates using the recA gene primers. a PCR product of the genes encoding $L b$. plantarum. b PCR product of the genes encoding LC. mesenteroides. c PCR product of the genes encoding Lactococcus lactis subsp. lactis. Lane L, 1000 bp ladder. Lane Neg, negative control. Lane Pos, positive control; lane numbers $(1,2,3 \ldots)$ amplicons from DNA isolated from selected LAB colonies

were incubated in anaerobic conditions, which may also reduce the effect of hydrogen peroxide against the indicators [37]. After the elimination of possible other antibacterial factors, only 30 LAB strains show antagonistic activity against 4 foodborne pathogens and recorded a different inhibitory spectrum of activity against Grampositive as well as Gram-negative bacteria. In this context, Mohamed et al. [38] revealed that cell free supernatant of lactic acid strains had varying degrees of inhibition towards both Gram-positive and Gramnegative bacteria. In harmony with our results, Azizi et al. [39] have found that Staph. aureus ATCC 25923 was more sensitive to bacteriocin of isolated LAB strains from Iranian raw milk Motal cheese.

Crude bacteriocin of isolated LAB strains in this study shows no activity against $L$. monocytogenes. This result 


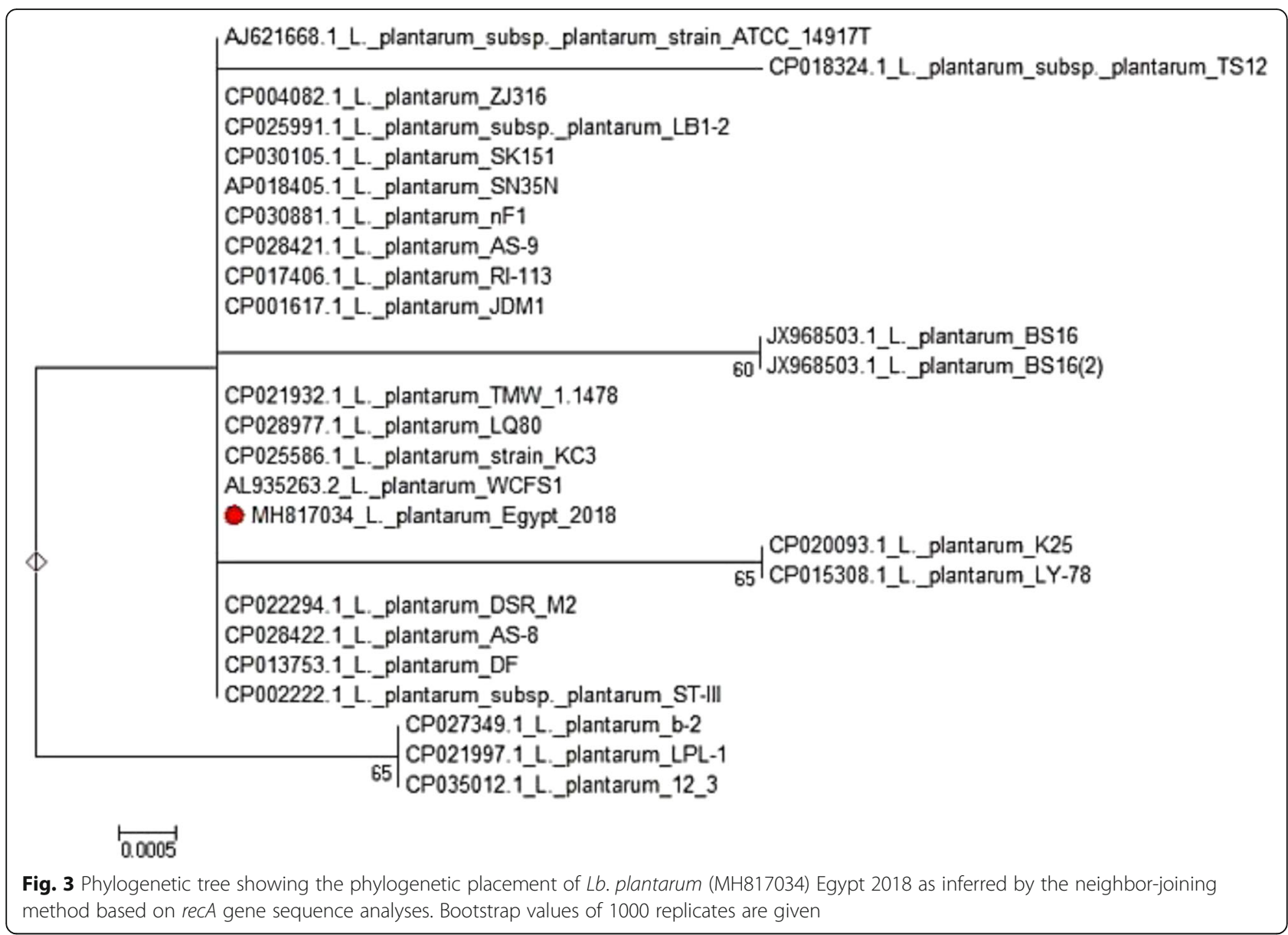

resembles the outcomes obtained by CFN supernatants of strains isolated from Korycinski cheese [40]. Also, Sip et al. [41] found that only 7 out of 800 LAB strains have the ability to inhibit the growth of $L$. monocytogenes. Demir and Basbülbül [42] anticipated that some bacteriocins have very narrow targets, so it is a key point to choose sensitive indicator strains. Bacteriocin production also influenced by many other factors like $\mathrm{pH}$, nutrient source, and incubation temperature [43].

It has been proposed that the recA gene could be used as a phylogenetic marker for distantly related species, and it has previously given adequate results for many bacterial genera [44]. The choice of specific $r e c A$ gene-based primers was based on phenotypic characterization and the available database gathered about the frequently identified isolates from fermented milk products. The results emphasize that the predominant bacteriocin producers comprise $L b$. plantarum (32\%) and Lc. mesenteroides (11.7\%). These findings are familiar with those reported by other workers, where the percentage of incidence was reported within the range 9-23\% for $L b$. plantarum $[45,46]$, which as well agreed with an earlier report about the identification of $L b$. plantarum as the predominant species isolated from other milk cheeses [47], also with Arizcun et al.
[48] who found that the predominant species in two types of cheeses were $L b$. plantarum, $L b$. casei, and $L c$. mesenteroides.

In the present study, Lb. plantarum strains showed antibacterial activity against 4 studied indicators; these results present a close similarity with Azizi et al. [39] as they establish that all $L b$. plantarum isolated from Iranian raw milk Motal cheese possess antibacterial activities against 3 indicators. Furthermore, Sankar et al. [49] observed that $L b$. plantarum isolates from raw cow milk samples had powerful antimicrobial activity against some of the indicator microorganisms.

From the populous Lactobacillus, Lb. plantarum is the most valuable species with beneficial properties, which is abundant in fermented foodstuffs from various habitats such as milk and cheese. $L b$. plantarum can grow at temperatures between 15 and $45^{\circ} \mathrm{C}$ and under acidic conditions with a pH as low as 3.2 [50]. Former studies demonstrated that the number of $L b$. plantarum cells increase considerably during cheese ripening among nonstarter $\mathrm{LAB}$ identified along with other species [51, 52]. On the other hand, Leuconostoc species are used as flavor forming culture due to their ability to enhance buttery aroma, produce a number of volatile flavor compounds, and iconic slimy texture in many dairy products. 


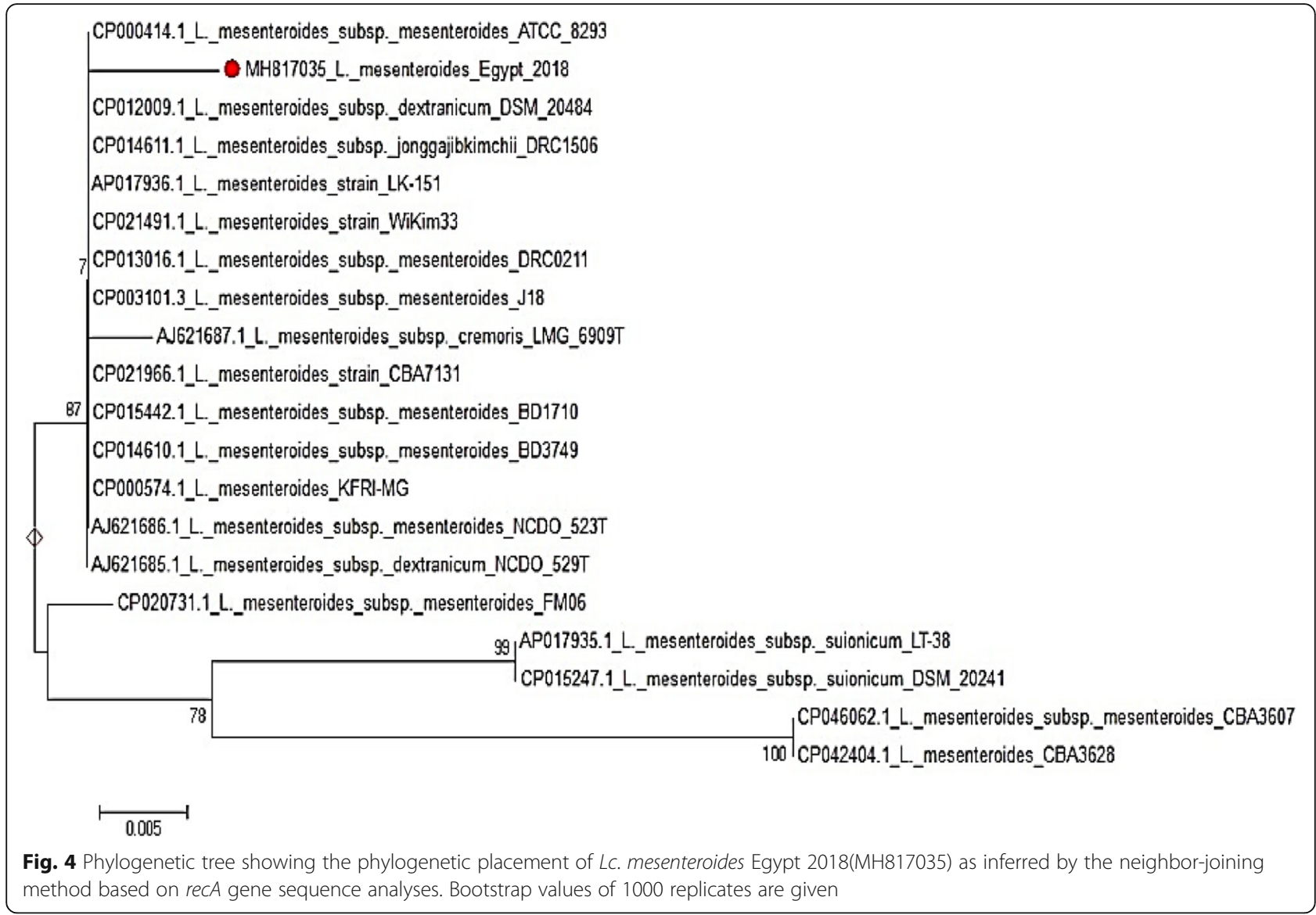

Table 5 PCR amplification of bacteriocin genes from $L b$. plantarum and LC. mesenteroids isolates

\begin{tabular}{|c|c|c|c|c|c|}
\hline \multirow[t]{2}{*}{ Strain no. } & \multirow[b]{2}{*}{$P \ln A$} & \multicolumn{3}{|c|}{ Bacteriocin gene } & \multirow[t]{2}{*}{ Bacteriocins activities (AU/ml) } \\
\hline & & $P \ln \mathrm{EF}$ & $P \ln C$ & MesY & \\
\hline 2 & - & $\mathrm{N}$ & $\mathrm{N}$ & $\mathrm{N}$ & 80 \\
\hline 16 & + & N & $\mathrm{N}$ & $\mathrm{N}$ & 80 \\
\hline 1 & $\mathrm{~N}$ & + & $\mathrm{N}$ & $\mathrm{N}$ & 40 \\
\hline 7 & $\mathrm{~N}$ & + & + & - & 80 \\
\hline 13 & $\mathrm{~N}$ & + & $\mathrm{N}$ & $\mathrm{N}$ & 160 \\
\hline 19 & $\mathrm{~N}$ & - & $\mathrm{N}$ & $\mathrm{N}$ & 80 \\
\hline 15 & $\mathrm{~N}$ & + & + & - & 80 \\
\hline 18 & $\mathrm{~N}$ & + & + & - & 40 \\
\hline 22 & $\mathrm{~N}$ & + & + & - & 80 \\
\hline 24 & $\mathrm{~N}$ & + & + & - & 80 \\
\hline 27 & $\mathrm{~N}$ & + & + & - & 80 \\
\hline
\end{tabular}

$(+)$ gene present, $(-)$ absence of gene, $(\mathrm{N})$ not performed PCR for determine that carried genes bacteriocin
Leuconostocs have proved to increase the safety of food by producing a variety of antimicrobial compounds including hydrogen peroxide and antimicrobial peptides $[53,54]$. The low numbers of leuconostocs identified from milk may possibly be explained by the complex nutritional requirements of these bacteria [55]. In recent years, isolation of Lc. mesenteroides, Lc. dextranicum, and Lc. pseudomesenteroides is more common from starter cultures or from cheese derivatives [56-58]. It is worth to mention that some strains of $L b$. plantarum and Lc. mesenteroides are exopolysaccharides producers; exopolysaccharides are large, structurally diverse polysaccharides that permeate the extracellular environment in the form of capsules or biofilms, and these molecules can help bacteria to survive extreme environmental conditions [59], which suggested that these exopolysaccharides might be the reason for the predominance of these two species in this study. Also, it could be supposed that the microbial diversity of these genera is strongly related to the source from which it was isolated as well as the environment climate.

LAB strains were analyzed by PCR for rapid screening of bacteriocins-encoding genes; this technique can be an alternative method to indicate the possibility of bacteriocin production, especially when multiple species present in natural samples such as milk and fermented food [60]. According to the present study, we have 


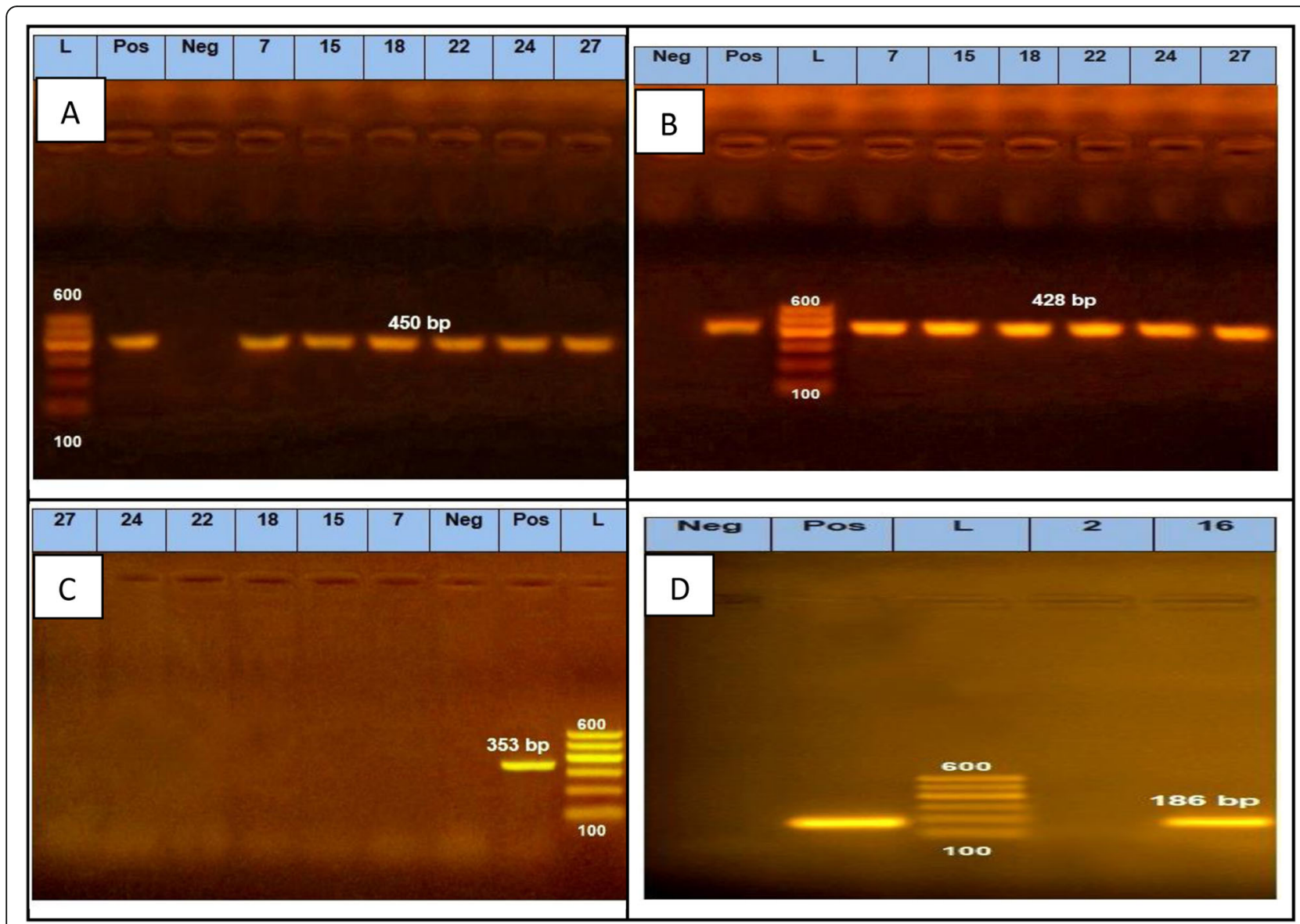

Fig. 5 Electrophoresis gel of PCR for detection of bacteriocins genes from the selected strains using primers pairs. a plnA. b plnEF. c plnC. d mesY. Lane L, 1000 bp ladder. Lane Neg, negative control. Lane Pos, positive control

avoided choosing of subclass IIa genes of bacteriocin in Lb. plantarum strains, which are known to be active against $L$. monocytogenes. From BAGEL and BLAST bacteriocin screens conducted by Collins et al. [61], we were able to possibly predict bacteriocin operons from the Lactobacillus Genus Complex. Thus, the most common bacteriocin's genes which were previously detected for Lb. plantarum strains were mostly related to class IIb bacteriocin. Besides, some studies have reported that certain strains of $L b$. plantarum are capable to produce more than one peptide with synergistic antibacterial effect, probably class IIb bacteriocins [62]. Based on the observation of the PCR product, it revealed the high incidence of these two non-lantibiotic bacteriocin's genes (pln $\mathrm{A}$ and $p \ln \mathrm{EF}$ ) in Lb. plantarum isolates among them strain Lb. plantarum Egypt 2018, while these bacteriocin's genes were absent in one strain (no. 19). Plantaricin EF is a two-peptide bacteriocin $(p \ln \mathrm{E}$ and $p \ln \mathrm{F})$ that depends on the complementary and synergistically action of two different peptides to function. These two-peptide bacteriocins act by binding to a specific membrane protein (a bacteriocin receptor) that leads to membrane leakage and cell death [63]. L. plantarum strains have reported to produce more than one bacteriocin. For example, $L b$. plantarum $\mathrm{C}-11$ isolated from fermented cucumbers [64] produces two-peptide bacteriocins, plantaricin EF, and plantaricin JK. On the other hand, plantaricin A, previously incorrectly identified as the bacteriocin responsible for inhibitory activity by $L b$. plantarum $\mathrm{C} 11$, may be considered a group II onepeptide bacteriocin, although it is a less potent antagonist than $p \ln \mathrm{EF}$ and $p \ln \mathrm{JK}$, but it gives an additive antibacterial activity [65]. Sharing our results, Azizi et al. [39] confirmed the presence of $p \ln \mathrm{EF}$ and $p \ln \mathrm{A}$ genes in all identified $L b$. plantarum strains. Unlikely, plantaricin $C$, a lantibiotic bacteriocin produced by a $L b$. plantarum strain of dairy origin [66] was absent in tested strains.

Whereas mesY gene was found in one of two strains of Lc. mesenteroides. The mesY gene encodes mesentericin Y105 (Mes-Y105) is a class IIa bacteriocin produced by Lc. mesenteroides Y105 [67]. Hechard et al. [68] indicated that mesentericin Y105 decreases membrane potential and oxygen consumption of Listeria cells by using flow cytometry and oximetry analysis. Thus, existing of 
this gene with no anti-listeria activity may be related to the development of natural resistance in listeria species to this bacteriocin [69]. When studying strains from the animal and human microbiota encoding bacteriocins, Collins et al. [60] concluded that there maybe is a link between the strains' environment and bacteriocin production. Also, the present study suggests the same theory. The environmental factors and sources could not only control the biodiversity of LAB strains but also the distribution of bacteriocin-encoding genes. Yet, the presence of bacteriocin genes does not necessarily reflect their antibacterial potential as they also depend on other environmental factors and genetic mutations. So combining both molecular techniques and in vitro screening approach has enabled us to explore the persistence of bacteriocins across the genus.

\section{Conclusion}

Up to the best of our knowledge, the present study is the first report on the isolation and screening of bacteriocinogenic LAB from Upper Egypt dairy products and detecting their bacteriocin-encoding genes. Lb. plantarum and Lc. mesenteroides were the predominant bacteriocin producers. The identified isolates recorded a good antibacterial activity mainly against Gram-positive indicators and some Gram-negative ones. The presence of $22 \mathrm{~L}$. plantarum strains and most of those strains shared the presence of two non-lantibiotic bacteriocin's genes $(p \ln \mathrm{A}$ and $p \ln \mathrm{EF})$ suggested that there might be a strong link between the strains' environment and their distribution as well as their ability to produce bacteriocins. The present study was useful and timely to develop a rapid and reliable method that could be used for the identification of common LAB species and also to determine their bacteriocinogenicity in various fermented milk samples. More studies are needed to be conducted about the safe application of these bacteriocins as an important source for using as biopreservatives in foods or as a natural substitute for antibiotics.

\begin{abstract}
Abbreviations
LAB: Lactic acid bacteria; GC: Glycine-cysteine; GRAS: Generally recognized as safe; PCR: Polymerase chain reaction; ÉCLAIR programme: European Collaborative Linkage of Agriculture and Industry through Research 19881993; recA: Recombinase A; MRS: Man-Rogosa and Sharpe; CFU: Colony forming unit; pH: Pondus hydrogenii (quantity of hydrogen); AU: Arbitrary unit; DNA: Deoxyribonucleic acid; Lc: Leuconostoc; Lb: Lactobacillus; bac+: bacteriocin positive; bp: Base pair; rRNA: Ribosomal ribonucleic acid; NCBI: National Center for Biotechnology Information; SD: Standard deviation
\end{abstract}

\section{Acknowledgements}

Authors are grateful to Dr. Ahmed Erfan—Reference lab for veterinary quality control on poultry, Animal health research institute, Dokki, Giza, Egypt, towards molecular aspects of this work.

\section{Authors' contributions}

SAA and MAM conceived and designed the experiments. RR performed the experiment. RR and SA wrote the manuscript. SAA, MAM, and HMA analyzed the data. SA reviewed and revised the manuscript, and HMA supervised and validated the data. All authors have read and approved the manuscript

Funding

Not applicable

\section{Availability of data and materials}

Authors declare that all generated and analyzed data are included in the article. The genome sequences of Lactobacillus plantarum Egypt 2018 and Leuconostoc mesenteroides Egypt 2018 have been deposited in GENBANK under accession numbers of MH817034 [https://www.ncbi.nlm.nih.gov/ nuccore/MH817034] and MH817035 [https://www.ncbi.nlm.nih.gov/nuccore/ MH817035], respectively.

Ethics approval and consent to participate

Not applicable

\section{Consent for publication}

Not applicable

\section{Competing interests}

The authors declare that they have no competing interests

\section{Author details}

${ }^{1}$ Health Affair, Luxor bacteriological laboratory, Luxor, Egypt. ${ }^{2}$ Department of Microbiology, Faculty of Science, Ain Shams University, Cairo, Egypt. ${ }^{3}$ Agricultural Research Centre (ARC), Food Technology Research Institute (FTRl), Giza, Egypt.

Received: 11 February 2020 Accepted: 30 April 2020

Published online: 19 June 2020

\section{References}

1. Ross RP, Morgan S, Hill C (2002) Preservation and fermentation, past, present and future. Int J Food Microbiol 79:3-16. doi:https://doi.org/10.1016/ S0168-1605(02)00174-5.Rakhmanova et al, 2018

2. Rakhmanova A, Khan ZA, Shah K (2018) A mini review fermentation and preservation: role of lactic acid bacteria. MOJ Food Process Technol 6(5): 414-417. https://doi.org/10.15406/mojfpt.2018.06.00197

3. Alnakip MEA, Mohamed AS, Kamal RM, Elbadry S (2016) Diversity of lactic acid bacteria isolated from raw milk in Elsharkia province, Egypt. Japanese J Veterinary Research 64:23-30 10.3205\%2Fdgkh000300

4. Cogan TM, Barbos M, Beuvier E, Branchi-Salvodari B, Cocconcelli PS, Fernandes I, Gomez J, Gomez R, Kalantzopoulos G, Ledda A, Medina M, Rea MC, Rodriguez E (1997) Characterization of the lactic acid bacteria in artisanal dairy products. Int Dairy Res 64:409-421

5. Leroy F, De Vuyst $L$ (2010) Bacteriocins of lactic acid bacteria to combat undesirable bacteria in dairy products. Aus J Dairy Technol 65:143-149

6. Todorov SD (2009) Bacteriocins from Lactobacillus plantarum - production, genetic organization and mode of action, produção, organização genética e modo de ação. Braz J Microbiol 40(2):209-221. https://doi.org/10.1590/ S1517-83822009000200001

7. Kao YT, Liu YS, Shyu YT (2007) Identification of Lactobacillus spp. in probiotic products by real-time PCR and melting curve analysis. Food Res. Int. 40:71-79. https://doi.org/10.1016/j.foodres.2006.07.018

8. Więckowicz M, Schmidt M, Sip A, Grajek W (2011) Development of a PCRbased assay for rapid detection of class Ila bacteriocin genes. Lett Appl Microbiol 52:281-289. https://doi.org/10.1111/j.1472-765X.2010.02999.x

9. Macwana SJ, Muriana PMA (2012) 'bacteriocin PCR array' for identification of bacteriocin-related structural genes in lactic acid bacteria. J Microbiol Methods 88:197-204. https://doi.org/10.1016/j.mimet.2011.11.008

10. Satokari RM, Vaughan EE, Smidt H, Saarela M, Matto J, De Vos WM (2003) Molecular approaches for the detection and identification of bifidobacteria and lactobacilli in the human gastrointestinal tract. Syst Appl Microbiol 26: 572-584. https://doi.org/10.1078/072320203770865882

11. De Man JC, Rogosa M, Sharpe ME (1960) A medium for the cultivation of lactobacilli. J Appl Bacteriol 23:130-135

12. Patil MM, Ramana TKWA (2010) Isolation and characterization of lactic acid bacteria from curd and cucumber. Indian J Biotechnol 9:166-172

13. Harley JP, Prescott LM (2002) Laboratory exercises in microbiology, Fifth Edition, The McGraw-Hill Companies 2002 Sneath PHA, Mair NS, Sharp ME 
(1986) Bergey's Manual of systematic Bacteriology, editor-in-chief JG Holt, vol.2. Baltimore, Maryland, Williams Wilkins.

14. Jensen M, Ardö Y, Vogensen F (2009) Isolation of cultivable thermophilic lactic acid bacteria from cheeses made with mesophilic starter and molecular comparison with dairy-related Lactobacillus helveticus strains. Letters Appl Microbiol 49:396-402. https://doi.org/10.1111/j.1472-765X.2009. 02673.x

15. Makhloufi KM, Carre'-Mlouka A, Peduzzi J, Lombard C, Van Reenen CA, Dicks LMT, Rebuffat S (2013) Characterization of Leucocin B-KM432Bz from Leuconostoc pseudomesenteroides isolated from Boza, and comparison of its efficiency to Pediocin PA-1. PLoS ONE, 8(8): e70484. https://doi.org/10.1371/ journal.pone.0070484

16. Toba T, Samant S, Itoh T (1991) Assay system for detecting bacteriocin in microdilution wells. Lett Appl Microbiol 13:102-104. https://doi.org/10.1111/ j.1472-765X.1991.tb00581.x

17. Karthikeyan V, Santosh SW (2009) Isolation and partial characterization of bacteriocin produced from Lactobacillus plantarum. Afr J M icrobiol Res 3(5): 233-239

18. Feliatra F, Muchlisin ZA, Teruna HY, Utamy, WR, Nursyirwani N, Dahliatyet A (2018) Potential of bacteriocins produced by probiotic bacteria isolated from tiger shrimp and prawns as antibacterial to Vibrio, Pseudomonas, and Aeromonas species on fish. F1000R- esearch 7:415. https://doi.org/10.12688/ f1000research.13958.1.

19. Wang D, Liu W, Ren Y, De L, Zhang D, Yang Y, Bao Q, Zhang H, Menghe B (2016) Isolation and identification of lactic acid bacteria from traditional dairy products in Baotou and Bayannur of Midwestern Inner Mongolia and q-PCR analysis of predominant species. Korean J Food Sci An 36(4):499-507. https://doi.org/10.5851/kosfa.2016.36.4.499

20. Sambrook J, Fritscgh EF, Mentiates T Cold Spring Harbor Laboratory.1989. Molecular cloning: a laboratory manual (2nd ed). Cold Spring Harbor Laboratory Press, N.Y.

21. Khalil SA, Bkheet AA, Gad Allah FA (2017) Genetic diversity of Pasteurella Multocida isolated from different animal species. Alexandria Journal of Veterinary Sciences 54:173-178. https://doi.org/10.5455/ajvs.263961.

22. Tamura K, Stecher G, Peterson D, Filipski A, Kumar S (2013) MEGA6: molecular evolutionary genetics analysis version 6.0. Mol Biol Evol 30:27252729. https://doi.org/10.1093/molbev/mst197.

23. Xiraphi N, Georgalaki M, Rantsiou K, Cocolin L, Tsakalidou E, Drosinos EH (2008) Purification and characterization of a bacteriocin produced by Leuconostoc mesenteroides E131. Meat Science 80:194-203

24. Tsapieva A, Duplik N, Suvorov A (2011) Structure of plantaricin locus of Lactobacillus plantarum 8P-A3. Benef Microbes 1, 2(4): 255-61. https://doi. org/10.3920/BM2011.0030.

25. Rizzello CG, Filannino P, Di Cagno R, Calasso M, Gobbetti M (2014) Quorumsensing regulation of constitutive plantaricin by Lactobacillus plantarum strains under a model system for vegetables and fruits. Appl Environ Microbiol 80(2):777-787

26. Beresford TP, Fitzsimons NA, Brennan NL, Cogan TM (2001) Recent advances in cheese microbiology. International Dairy J 11:259-274

27. Karimi R, Mortazavian AM, Da Cruz AG (2011) Viability of probiotic microorganisms in cheese during production and storage, a review. Dairy Sci Technol 91:283-308

28. Sowmya Y (2017) A Short Review on Milk Spoilage. RJFPDT 5:1-5

29. Amer E, Mahrous H, Shekib LA (2017) Isolation and identification of probiotic lactic acid bacteria from dairy products. Biotechnol Res 3:65-70 10.3205\%2Fdgkh000300

30. Medeiros RS, Araújo LM, Queiroga Neto V, Andrade PP, Melo MABP, Gonçalves MM (2016) Identification of lactic acid bacteria isolated from artisanal Coalho cheese produced in the Brazilian Northeast. CyTA-J Food 14(4):613-620. https://doi.org/10.1080/19476337.1185468

31. Moulay M, Benlancen K, Aggad H, Kihal M (2013) Diversity and technological properties of predominant lactic acid bacteria isolated from Algerian raw goat milk. Advances in Environmental Biology 7(6):999-1007

32. Yelnetty A, Purnomo H, Purwadi Mirah A (2014) Biochemical characteristics of lactic acid bacteria with proteolytic activity and capability as starter culture isolated from spontaneous fermented local goat milk. J Nat Sci Res 4(10):137-146

33. Jagadeeswari S, Vidya PDJ, Kumar M, Balakumaran MD (2010) Isolation and characterization of bacteriocin producing lactobacillus sp. from traditional fermented foods. Electronic J Environ Agricult Food Chem 9:575-581
34. Franciosi E, Settanni L, Cavazza A, Poznanski E (2009) Biodiversity and technological potential of wild lactic acid bacteria from raw cows' milk. Int Dairy J 19:3-11

35. Brooks JC, Martinez B, Stratton J, Bianchini A, Krokstrom R, Hutkins R (2012) "Survey of raw milk cheeses for microbiological quality and prevalence of foodborne pathogens. Food Microbiology 31 (2):154-158.

36. Jackson K, Gould L, Hunter JC, Kucerova Z, Jackson B. Listeriosis outbreaks associated with soft cheeses, United States, 1998-2014 (2018) Emerg Infect Dis.24(6):1116-1118. https://doi.org/10.3201/eid2406.171051

37. Schillinger U, Lucke FK (1989) Antibacterial activity of Lactobacillus sake isolated from meat. Appl Environ Microbiol 55:1901-1906

38. Mohamed WF, Abu Shady HM, Sayed -Ahmed El-SF, Amer SA (2016) Antibacterial activity of Egyptian propolis and pollen extractions and their synergistic/antagonistic effect with lactic acid bacteria $L A B$ ) against food borne pathogenic bacteria, Egypt. J Exp Biol Bot 12: 31-43

39. Azizi F, Habibi Najafi MB, Edalatian Dovom MR (2017) The biodiversity of Lactobacillus spp. from Iranian raw milk Motal cheese and antibacterial evaluation based on bacteriocin-encoding genes. AMB Express 7 1:176. 10.1186/s13568-017-0474-2.

40. Ołdak A, Zielińska D, Rzepkowska A, Kołożyn-Krajewska D (2017) Comparison of antibacterial activity of Lactobacillus plantarum strains isolated from two different kinds of regional cheeses from Poland, Oscypek and Korycinski Cheese. BioMed Research International pp: 10. https://doi.org/10.1155/2017/ 6820369

41. Sip A, Więckowicz M, Olejnik-Schmidt A, Grajek W (2012) Anti-Listeria activity of lactic acid bacteria isolated from golka, a regional cheese produced in Poland. Food Control 26:117-124. https://doi.org/10.1016/j. foodcont.2012.01.014

42. Demir E, Basbülbül G (2017) Screening of bacteriocin production in lactic acid bacteria isolated from fermented dairy products. BJ 33504(18):1-9

43. Gupta A, Sharma N (2017) Characterization of potential probiotic lactic acid bacteriaPediococcus acidilactici Ch-2 Isolated from Chuli- a traditional apricot product of Himalayan region for the production of novel bioactive compounds with special therapeutic properties. J Food Microbiol Saf Hyg 2:119

44. Kullen MJ, Brady LJ, O'sullivan DJ (1997) Evaluation of using a short region of the recA gene for the rapid and sensitive speciation of dominant bifidobacteria in the human large intestine. FEMS Microbiol Lett., 154, 377383. https://doi.org/10.1111/j.1574-6968.1997.tb12670.x

45. Tambekar D, Bhutada S (2010) Studies on antimicrobial activity and characteristics of bacteriocins produced by Lactobacillus strains isolated from milk of domestic animals. Int J Microbiol. 8(2)

46. Mabrouk AMM, Effat BAM, Sadek ZIM, Tawfik NF, Hassan ZMR, Magdoub MNI (2014) Antibacterial activity of some lactic acid bacteria isolated from Egyptian dairy products. Int J Chem Tech Res 6(2):1139-1150

47. Medina R, Katz M, Gonzalez S, Oliver G (2001) Characterization of the lactic acid bacteria in ewe's milk and cheese from northwest Argentina. J Food Prot 64(4):559-563

48. Arizcun C, Barcina Y, Torre P (1997) Identification of lactic acid bacteria isolated from Roncal and Idiazâbal cheeses. Lait77:729-736.

49. Sankar NR, Priyanka VD, Reddy PS, Rajanikanth P, Kumar VK, Indira M (2012) Purification and characterization of bacteriocin produced by Lactobacillus plantarum isolated from cow milk. Int J Microbiol Res. 3:133-137

50. Smetankova J, Hladı 'kova Z, Valach F, Zimanova' M, Kohajdova' Z, Greif G, Greifova' M (2012) Influence of aerobic and anaerobic conditions on the growth and metabolism of selected strains of Lactobacillus plantarum. Acta Chim. Slov. 5: 204-210.

51. Rantsiou K, Urso R, Dolci P, Comi G, Cocolin L (2008) Microflora of feta cheese from four Greek manufacturers. Int J Food Microbiol. 126:36-42. https://doi.org/10.1016/j.ijfoodmicro.2008.04.031

52. Berta G, Chebenov V, Brezna B, Pangallo D, Valik L, Kuchta T (2009) Identification of lactic acid bacteria in Slovakian bryndza cheese. J Food Nutr Res 48:65-71

53. Thunell R (1995) Taxonomy of the leuconostocs. J Dairy Sci 78:2514-2522

54. Kihal M, Prevost $H$, Henni DE, Benmechernene Z, Diviès C (2007) Carbon dioxide production by Leuconostoc mesenteroides grown in single and mixed culture with Lactococcus lactis in skimmed milk. World J Dairy Food Sci 2:62-68

55. Garvie El (1984) Separation of species of the genus Leuconostoc and differentiation of Leuconostoc from other lactic acid bacteria. Methods Microbiol 16:148-177 
56. Kleppen HP, Nes IF, Holo H (2012) Characterization of a Leuconostoc bacteriophage infecting flavor producers of cheese starter cultures. Appl Environ Microbiol 78(18):6769-6772

57. Pedersen TB, Kot WP, Hansen LH, Sørensen SJ, Broadbent JR, Vogensen FK Ardö Y (2014) Genome sequence of Leuconostoc mesenteroides subsp. cremoris strain T26, isolated from mesophilic undefined cheese starter. Genome Announc. 5; 2(3).

58. Østlie HM, Kraggerud H, Longva AB, Abrahamsen RK (2016) Characterization of the microflora during ripening of a Norwegian semi-hard cheese with adjunct culture of propionic acid bacteria. Int Dairy J 54:43-49. https://doi. org/10.1016/j.idairyj.2015.10.005

59. Zeidan AA, Poulsen VK, Janzen T, Buldo P, Derkx PMF, Øregaard G, Neves AR (2017) Polysaccharide production by lactic acid bacteria: from genes to industrial applications. FEMS Microbiology Reviews fux017 41: S168-S200. https://doi.org/10.1093/femsre/fux017.

60. Yi H, Zhang L, Tuo Y, Han X, Du M (2010) A novel method for rapid detection of class lla bacteriocin-producing lactic acid bacteria.

61. Collins FWJ, O'Connor PM, O'Sullivan O, Gómez-Sala B, Rea MC, Hill C, Ross P (2017) Bacteriocin gene-trait matching across the complete Lactobacillus pan-genome. Sci Rep 7:3481. https://doi.org/10.1038/s41598-017-03339-y

62. Maldonado A, Ruiz-Barba JL, Jim_Enez-Díaz R (2003) Purification and genetic characterization of plantaricin NC8, a novel coculture-inducible two-peptide bacteriocin from Lactobacillus plantarum NC8. Applied and Environmental Microbiology 69:383-389. https://doi.org/10.1128/AEM.69.1.383-389.2003

63. Ekblad B, Kyriakou PK, Oppegård C, Nissen-Meyer J, Kaznessis YN, Kristiansen PE (2016) Structure-function analysis of the two-peptide bacteriocin plantaricin EF. Biochemistry 55(36):5106-5116. https://doi.org/10.1021/acs. biochem.6b00588

64. Daeschel MA, Mckenney MC, Mcdonald LC (1990) Bacteriocidal activity of Lactobacillus plantarum C-11. Food Microbiol 7:91-98. https://doi.org/10. 1016/0740-0020(90)90014-9

65. Anderssen EL, Diep DB, Nes IF, Eijsink VGH, Nissen-Meyer J (1998) Antagonistic activity of Lactobacillus plantarum C11, two new two-peptide bacteriocins, plantaricins $\mathrm{EF}$ and $\mathrm{JK}$, and the induction factor plantaricin $\mathrm{A}$. Appl Environ Microbiol 64:2269-2272

66. Turner DL, Brennan L, Meyer HE, Lohaus C, Siethoff C, Costa HS, Gonzalez B, Santos H, Suarez JE (1999) Solution structure of plantaricin C, a novel lantibiotic. Europ J Biochem 264:833-839

67. Fremaux C, Hechard Y, Cenatiempo Y (1995) Mesentericin Y105 gene clusters in Leuconostoc mesenteroides Y105. Microbiology 141 (Pt7):1637-45. https://doi.org/10.1099/13500872-141-7-1637.

68. Hechard Y, Derijard B, Letellier F, Cenatiempo' $Y$ (1992) Characterization and purification of mesentericin $Y 105$, an anti-listeria bacteriocin from Leuconostoc mesenteroides. J Gen Microbiol 138:2725-2731 Printed in Great Britain 2125. https://doi.org/10.1099/00221287-138-12-2725.

69. Ennahar S, Sashihara T, Sonomoto K (2000) Ishizaki A (1999) Class Ila bacteriocins: biosynthesis, structure and activity. FEMS Microbiology Reviews 24:85-106

\section{Publisher's Note}

Springer Nature remains neutral with regard to jurisdictional claims in published maps and institutional affiliations.

\section{Submit your manuscript to a SpringerOpen ${ }^{\circ}$ journal and benefit from:}

- Convenient online submission

- Rigorous peer review

- Open access: articles freely available online

- High visibility within the field

- Retaining the copyright to your article

Submit your next manuscript at $\boldsymbol{\nabla}$ springeropen.com 